\title{
Adrianna Gęga-Czarnota
}

Beskidzkie Centrum Onkologii, Szpital Miejski im. Jana Pawła II w Bielsku-Białej

\section{Remisja czerniaka złośliwego z przerzutami do ośrodkowego układu nerwowego u 42-letniego chorego oraz stabilizacja choroby u 88-letniego chorego na czerniaka - skuteczność pembrolizumabu}

Remission of malignant melanoma with brain metastases in 42-year-old patient and stable disease in 88-year-old patient with melanoma - efficacy of pembrolizumab

\section{Adres do korespondencji:}

Lek. Adrianna Gęga-Czarnota Beskidzkie Centrum Onkologii - Szpital Miejski

ul. Wyzwolenia 18, 43-300 Bielsko-Biała e-mail: adrianna.gega@gmail.com

DOI: $10.5603 /$ OCP.2018.0058 Copyright $(C) 2018$ Via Medica ISSN 2450-1646

\section{STRESZCZENIE}

Czerniak to nowotwór skóry i błon śluzowych wywodzący się z melanocytów znamion barwnikowych lub niezmienionej skóry. Najczęstszą lokalizacją pierwszych przerzutów są węzły chłonne, skóra i tkanka podskórna, płuca, mózg, kości, wątroba oraz przewód pokarmowy. W ostatnich latach leczenie chorych na czerniaka uległo znacznej zmianie. Dostępne są nowe metody terapii, które poprawiają jakość życia chorych i wydłużają czas ich przeżycia, takie jak inhibitory BRAF i MEK, czy immunoterapia z zastosowaniem przeciwciał PD-1, na przykład pembrolizumabu. Przedstawiono przypadki 2 pacjentów: 42-letniego chorego na czerniaka, u którego po niepowodzeniu pierwszej linii leczenia zastosowano w drugiej linii pembrolizumab, uzyskując remisję choroby, oraz 88-letniego chorego w podeszłym wieku, u którego uzyskano stabilizację choroby.

Słowa kluczowe: czerniak, przerzuty do OUN, inhibitory BRAF i MEK, pembrolizumab, remisja

\section{ABSTRACT}

Melanoma is a cancer of the skin and mucous membranes that originates from melanocytes of pigmented nevi or unaltered skin. The most common locations of the first metastases are lymph nodes, skin and subcutaneous tissue, lungs, brain, bones, liver and digestive tract. In recent years, the treatment of melanoma patients has changed significantly. New methods of therapy are available that improve the quality of life of patients and prolong their survival, such as BRAF and MEK inhibitors, or immunotherapy with PD-1 antibodies, e.g. pembrolizumab. The paper presents two patients: 42-year-old patient with melanoma in whom, after the failure of the first line of treatment, pembrolizumab was used as the second line therapy, resulting in remission of the disease, and 88-year-old elderly patient with stable disease.

Key words: melanoma, brain metastases, BRAF and MEK inhibitors, pembrolizumab, remission 


\section{Wstęp}

Czerniak to rak skóry i błon śluzowych wywodzący się z melanocytów znamion barwnikowych lub niezmienionej skóry. Najczęstszą lokalizacją pierwszych przerzutów są węzły chłonne, skóra i tkanka podskórna, płuca, mózg, kości, wątroba oraz przewód pokarmowy. W ostatnich latach leczenie chorych na czerniaka uległo znacznej zmianie. Dostępne są nowe metody terapii, które poprawiają jakość życia chorych i wydłużają czas ich przeżycia, takie jak inhibitory BRAF i MEK, czy immunoterapia z zastosowaniem pembrolizumabu. Przedstawiono przypadki 2 pacjentów: 42-letniego chorego na czerniaka, u którego po niepowodzeniu pierwszej linii leczenia zastosowano w drugiej linii pembrolizumab, uzyskując remisję choroby, oraz 88-letniego chorego, u którego uzyskano stabilizację choroby.

\section{Opisy przypadków}

\section{Przypadek 1}

Mężczyzna lat 42, bez obciążeń internistycznych. W dniu 14 czerwca 2006 roku na Oddziale Chirurgii Onkologicznej Beskidzkiego Centrum Onkologii (BCO) wycięto guza skóry prawego podudzia oraz wykonano transplantację skóry metodą Thierscha.

W badaniu histopatologicznym rozpoznano czerniaka z owrzodzeniem, Clark IV, 5 mm według Breslowa. Chory został skierowany na konsultację do Centrum Onkologii - Instytutu im. M. Skłodowskiej-Curie w Warszawie, gdzie w dniu 17 sierpnia 2006 roku wykonano biopsję węzłów chłonnych wartowniczych sposobem Mortona i docięcie blizny z pokryciem ubytku przeszczepem skóry pobranym z uda lewego.

Po stwierdzeniu przerzutu w węźle wartowniczym 2 października 2006 roku wykonano limfadenektomię pachwinowo-biodrową lewostronną. Pacjent pozostawał pod obserwacją poradni onkologicznej od października 2006 roku do kwietnia 2016 roku.

W kwietniu 2016 roku chory został przyjęty w trybie pilnym na Oddział Neurochirurgii Szpitala Wojewódzkiego w Biesku-Białej z podejrzeniem krwiaka okolicy ciemieniowej prawej.

Usunięto ukrwotoczniony guz mózgu, w badaniu histopatologicznym potwierdzono przerzut czerniaka.

Po konsultacji onkologicznej w poradni BCO w Bielsku-Białej zaplanowano i przeprowadzono paliatywną radioterapię mózgowia Df 4 Gy w 5 frakcjach do Dc 20 Gy (od 19 maja 2016 r. do 24 maja 2016 r.) oraz kwalifikację do leczenia systemowego.

Stwierdzono obecność mutacji V600E genu $B R A F$. Aktywność dehydrogenazy mleczanowej (LDH, lactate dehydogenase) wynosiło 933 U/l (norma 240-480), hemoglobiny (Hb) 14,3 g/dl.

W badaniach obrazowych uwidoczniono nieoperacyjny rozsiew do otrzewnej oraz nowe ognisko przerzutowe w lewym płacie czołowym.

W badaniu przedmiotowym z odbiegnięć od normy stwierdzono: w prawym dole podkolanowym, przyśrodkowo guz $5 \times 6 \mathrm{~cm}$, a powyżej, na przyśrodkowej części uda, wszczep śródskórny wielkości $2 \mathrm{~cm}$.

Chorego zakwalifikowano do leczenia w ramach programu lekowego Narodowego Funduszu Zdrowia (NFZ) z zastosowaniem wemurafenibu i kobimetyninibu. Terapię prowadzono od 27 czerwca 2016 roku do 6 marca 2017 roku. W czasie jej trwania obserwowano toksyczności skórne, niewymagające jednak redukcji dawki leków. Czas leczenia do progresji wyniósł 8 miesięcy.

$\mathrm{W}$ momencie stwierdzenia progresji stężenie LDH pozostawało w normie.

W badaniu przedmiotowym stwierdzono masywną, dynamiczną progresję w obrębie guza w prawym dole podkolanowym (guz $13 \times 9 \mathrm{~cm}$ ), z napiętą, zaczerwienioną skórą (ryc. 1). W badaniach obrazowych zmiany w jamie brzusznej pozostawały nadal w całkowitej remisji, a resztkowe zmiany ogniskowe w ośrodkowym układzie nerwowym (OUN) były stabilne.

Pacjent został zakwalifikowany do immunoterapii w ramach programu lekowego NFZ pembrolizumabem. Leczenie rozpoczęto 23 marca 2017 roku. Po pierwszym podaniu pembrolizumabu obserwowano kliniczną częściową regresję zmiany w dole podkolanowym (ryc. 2). Do chwili obecnej chory otrzymał 24 podania leku.

Z toksyczności obserwowano: niedoczynność tarczycy (od 3. miesiąca leczenia) oraz bielactwo. W badaniach obrazowych - tomografii komputerowej (TK) głowy,

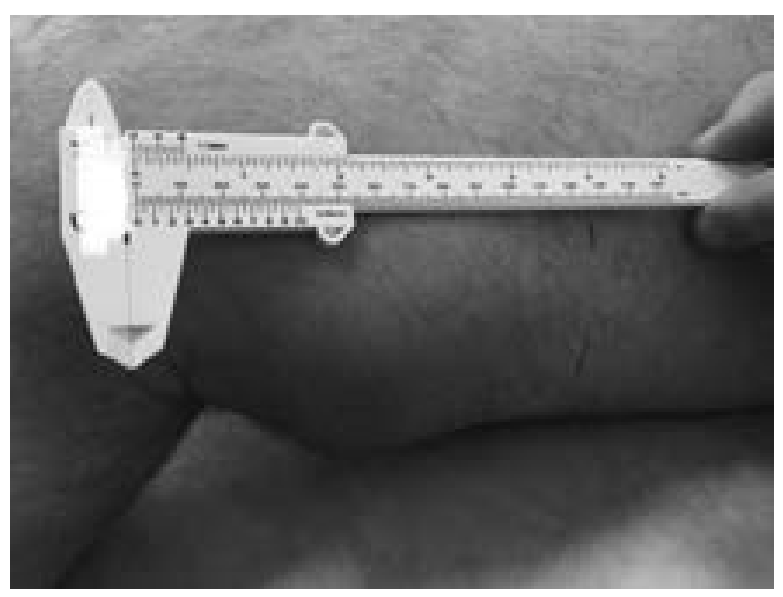

Rycina 1. Przed pierwszym cyklem pembrolizumabu guz $w$ dole podkolanowym $13 \times 9 \mathrm{~cm}$, skóra nad zmianą zaczerwieniona, ucieplona, napięta 


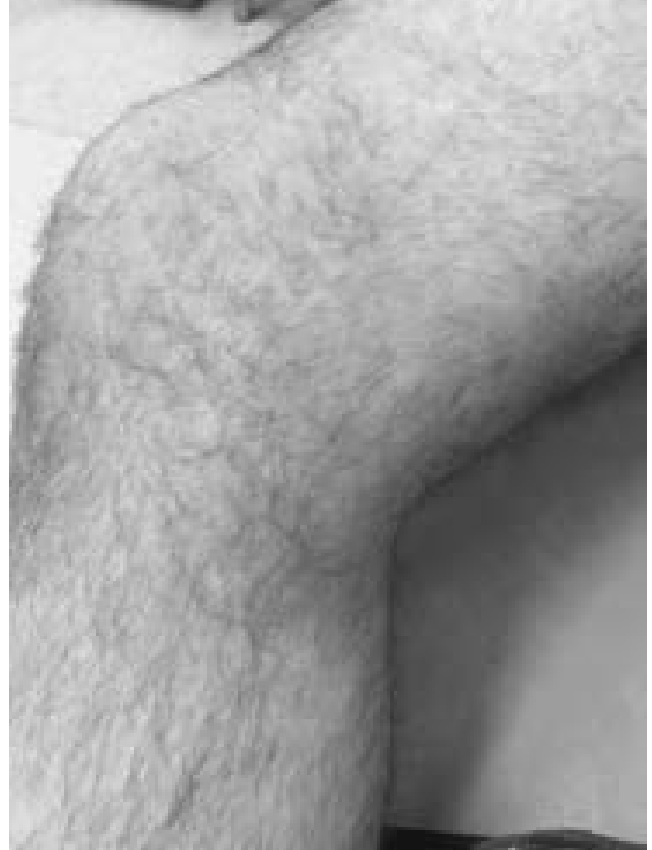

Rycina 2. Przed drugim cyklem pembrolizumabu - guz $8 \times 7 \mathrm{~cm}$, skóra nad guzem normalnie ucieplona, niezaczerwieniona

klatki piersiowej, jamy brzusznej i miednicy oraz w badaniu ultrasonograficznym (USG) dołu podkolanowego — od września 2017 roku do chwili obecnej utrzymuje się całkowita remisja.

\section{Omówienie}

W przypadku opisanego pacjenta w momencie kwalifikacji do leczenia pierwszej linii nie było wątpliwości, czy zacząć leczenie od inhibitorów BRAF/MEK, czy immunoterapii, gdyż program lekowy dla anty-PD-1 wszedł w życie dopiero kilka tygodni później.

Gdyby w momencie kwalifikacji były dostępne obie metody leczenia za opcją leczenia celowanego przemawiałaby szybka dynamika choroby - pojawienie się nowych zmian w OUN w bardzo krótkim czasie po radioterapii mózgowia — oraz podwyższone stężenie LDH. W trakcie leczenia inhibitorami BRAF/MEK wystąpiła typowa dynamiczna progresja. Była to jednak progresja w obrębie tylko jednego ogniska, a dzięki lokalizacji dobrze dostępnej w badaniu przedmiotowym, możliwe było szybkie jej wykrycie i włączenie drugiej linii leczenia. Do remisji wszystkich opisywanych wcześniej zmian doszło po 6 miesiącach leczenia pembrolizumabem.

\section{Przypadek 2}

Obecnie 88-letni pacjent $\mathrm{z}$ chorobami towarzyszącymi: nadciśnieniem tętniczym, przerostem gruczołu krokowego, chorobą Parkinsona (leczony z ich powodu ramiprylem, bisoprololem, lewodopą) zgłosił się w październiku 2017 roku do BCO w Bielsku-Białej na zaplanowany zabieg usunięcia guza lewego ramienia. W raporcie $z$ badania histopatologicznego ustalono rozpoznanie czerniaka. Typ histologiczny - guzkowy, z owrzodzeniem, głębokość naciekania według Breslowa 1,7 cm, głębokość naciekania według Clarka V, faza wzrostu — pionowa, radykalność - margines boczny po $0,3 \mathrm{~cm}$, margines głęboki $0,25 \mathrm{~cm}$, aktywność mitotyczna $3 / \mathrm{mm}^{2}$, bez cech regresji, z angioinwazją i naciekami zapalnymi, bez naciekania nerwów, bez guzków satelitarnych i utkania resztkowego znamienia.

W celu ustalenia stopnia zaawansowania choroby poszerzono diagnostykę. Wykonano biopsję aspiracyjną cienkoigłową (BAC) węzła chłonnego lewej pachy — stwierdzono obecność przerzutu czerniaka złośliwego. W badaniu TK klatki piersiowej, USG jamy brzusznej - bez cech rozsiewu.

Chorego zakwalifikowano do zabiegu operacyjnego. W styczniu 2018 roku wykonano limfadenektomię lewego dołu pachowego w bloku z przerzutem in transit w okolicy lewego mięśnia naramiennego — zabieg sposobem Pringla, wycięcie blizny po usunięciu czerniaka okolicy barku lewego, a także wycięcie guzka skóry okolicy naramiennej.

W badaniu histopatologicznym stwierdzono $35 \mathrm{~mm}$ przerzut w 1 z 14 pobranych węzłów chłonnych, nieprzekraczający torebki węzła oraz 3 przerzuty do tkanki podskórnej, 1 przerzut do skóry właściwej. Wszystkie zmiany zostały usunięte w całości. Blizna była wolna od utkania nowotworowego.

Po 2 miesiącach w badaniu przedmiotowym zaobserwowano na skórze w okolicy blizny 4 zmiany in transit wielkości do $10 \mathrm{~mm}$.

W kontrolnym badaniu TK klatki piersiowej, jamy brzusznej i miednicy stwierdzono progresję choroby — rozsiew do płuc wieloogniskowy z licznymi zmianami do $17 \mathrm{~mm}$ oraz, również wieloogniskowy, rozsiew do wątroby, wielkość zmian do $22 \mathrm{~mm}$. Nie stwierdzono mutacji V600E genu $B R A F$. Stężenie LDH wynosiło 336, a Hb 12,2 g/dl.

Pacjenta zakwalifikowano do leczenia pembrolizumabem. Leczenie rozpoczęto dnia 16 maja 2018 roku. W trakcie leczenia nie obserwowano toksyczności, stan ogólny pacjenta był dobry [1 wg skali Światowej Organizacji Zdrowia (WHO, World Health Organization)].

W pierwszym kontrolnym badaniu obrazowym opisano stabilizację choroby. W badaniu przedmiotowym odnotowano zmiany na skórze ramienia lewego stabilne. W badaniach biochemicznych: LDH 313 U/l, $\mathrm{Hb} 11,3 \mathrm{~g} / \mathrm{dl}$.

W badaniu obrazowym z października 2018 roku oraz w badaniu klinicznym nadal utrzymuje się stabilizacja choroby (ryc. 3, 4, 5). W badaniach biochemicz- 

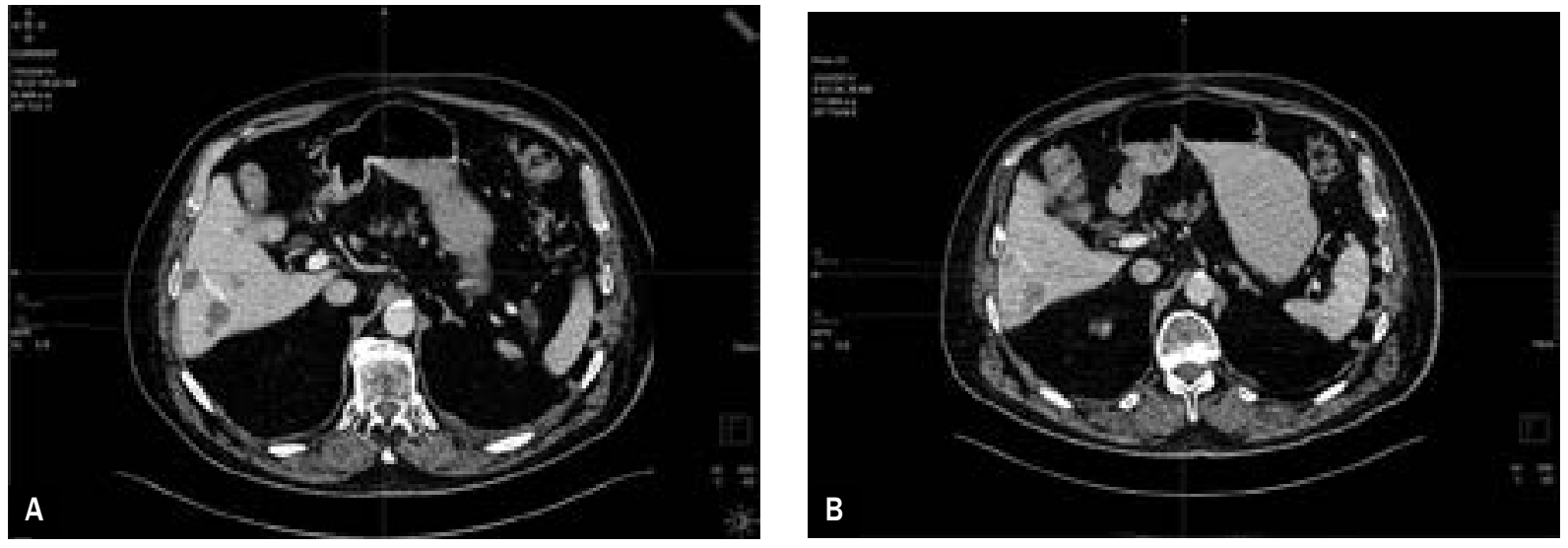

Rycina 3A.B. Stabilizacja zmian w wątrobie u 88-letniego pacjenta
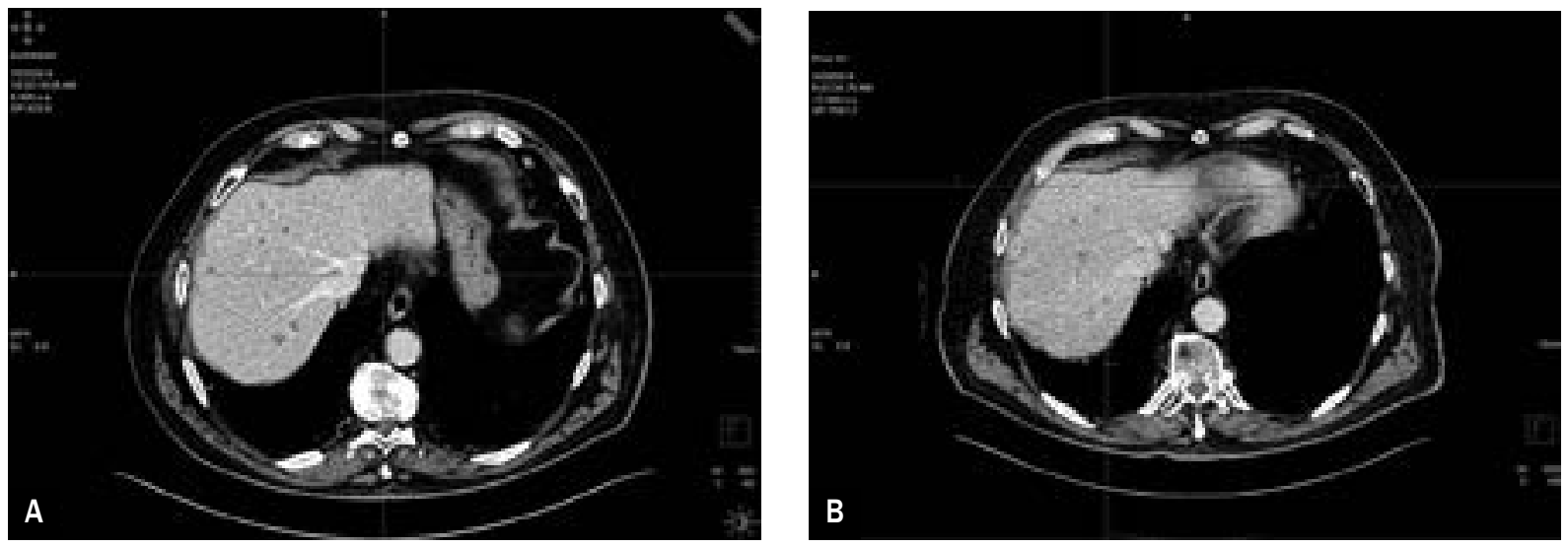

Rycina 4A.B. Stabilizacja zmian w wątrobie u 88-letniego pacjenta
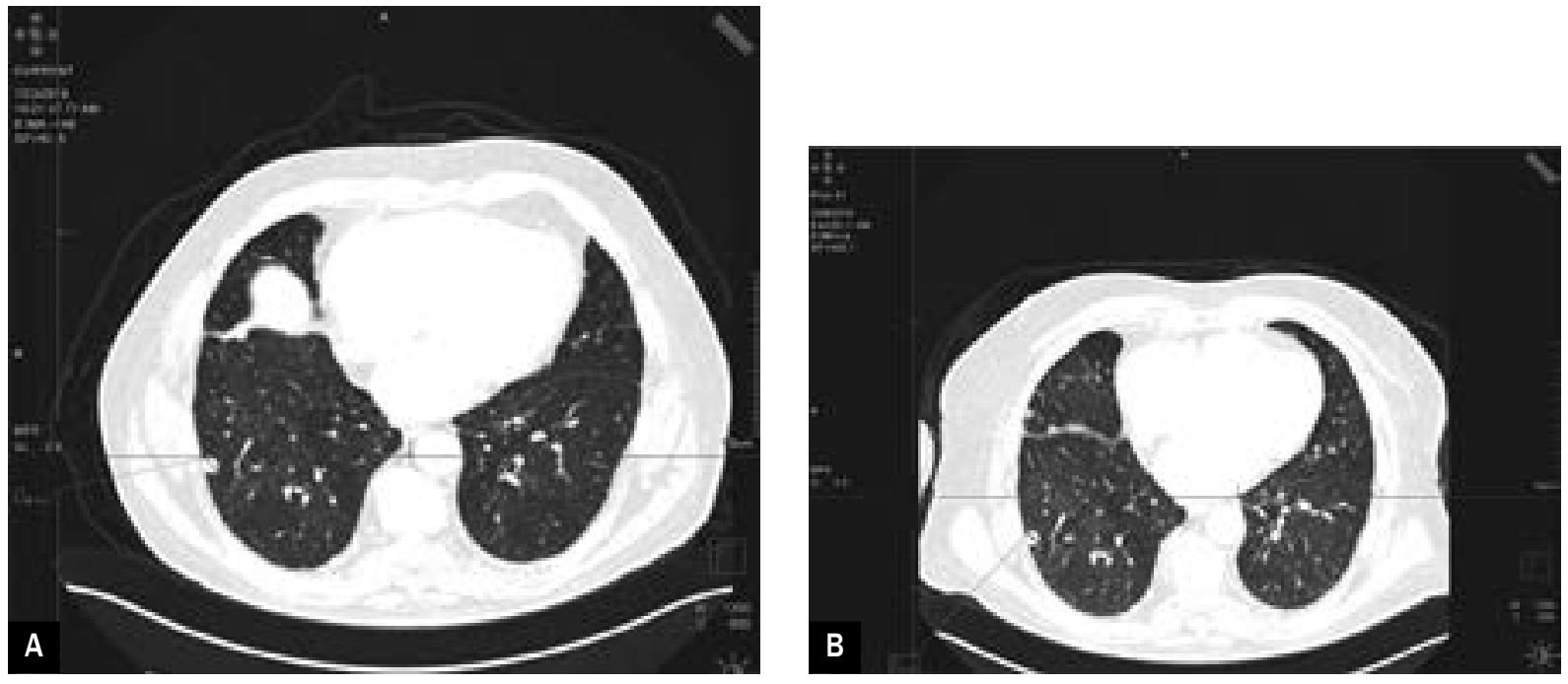

Rycina 5A.B. Stabilizacja zmian w płucach u 88-letniego pacjenta 
nych LDH - $300 \mathrm{U} / \mathrm{l}, \mathrm{Hb}-12 \mathrm{~g} / \mathrm{dl}$. Leczenie dobrze tolerowane, nie odnotowano toksyczności.

\section{Omówienie}

W przypadku opisywanego pacjenta niewątpliwe uwagę zwraca jego wiek. Biorąc jednak pod uwagę dotychczasowe doświadczenia w leczeniu immunoterapią osób w podeszłym wieku oraz dobrą kondycję fizyczną i umysłową pacjenta, przy jednoczesnym zapewnieniu opieki przez rodzinę, zdecydowano o rozpoczęciu lecze- nia. Obecnie (grudzień 2018 r.) pacjent nadal kontynuuje pembrolizumab. Uzyskano stabilizację choroby, nie obserwowano toksyczności.

\section{Piśmiennictwo}

1. Jassem J. (red.), Krzakowski M. (red.), Rutkowski P. (red.). Złośliwe nowotwory skóry. Praktyczny przewodnik dla lekarzy. Wyd. 2. Via Medica, Gdańsk 2014 